\title{
Role Change of Developed Countries and Emerging Economic Entities in Global Governance
}

\author{
Chaofan Chen ${ }^{1}$, Yun Wang ${ }^{1}$ \\ ${ }^{1}$ School of Economics and Resource Management, Beijing Normal University, Beijing, China. \\ Correspondence: Chaofan Chen, School of Economics and Resource Management, Beijing Normal University, Beijing, \\ China.
}

Received: July 5, 2015

Accepted: October 8, 2015

Available online: October 9, 2015

doi:10.11114/ijsss.v3i6.1119

URL: http://dx.doi.org/10.11114/ijsss.v3i6.1119

\begin{abstract}
With rapid development of globalization, numerous global problems appear, and global governance thus emerges. For a long time, the elite club G8 Group which consists of developed countries monopolizes and leads global governance, while vast developing countries are at the edge of global governance stage. However, due to increasingly complex and severe global problems, defects of G8 mechanism, low execution efficiency and legality problem, governance ability of G8 declines continuously. As emerging economic entities rise, G20 gradually replaces G8 and becomes a main mode of global governance. The role that emerging economic entities play stands out increasingly. In addition, participation in global governance by emerging economic entities intensively reflects interests and appeals of developing countries. In the future, emerging economic entities will become important force in politic and economic fields in the world.
\end{abstract}

Keywords: global governance, G8, emerging economic entities, role change

\section{Introduction}

After the end of Cold War, the contact among various countries in the world became increasingly close, and interdependency enhances continuously. Meanwhile, depth and range of globalization expanded greatly. Globalization makes international political and economic pattern change profoundly and promotes emergence of a series of global problems. These global problems involve politics, economy, society, resource and environment etc. and surpass the range of national governance ability. Traditional international governance system which regards countries as the subject suffers severe challenges. In this process, human political life also changes greatly. The center of political process moves to governance from rule, to favorable governance from good politics, to non-government governance from government-led governance and to global governance from national government rule. Global governance is both theory and practice. Although the theory of global governance is not mature and large disputes exists in some significant problems, undoubtedly global governance conforms to historical trend of political and economic development in the world and has great significance for establishing fair and rational new international political and economic order. In contemporary society, different countries and their people can coordinate and cooperate in the nonviolent way, effectively solve international problems and disputes and achieve maximization of common interests and value only through global governance. In the views of numerous scholars and decision makers, global governance is the most obvious characteristic of globalization era.

Meanwhile, with the arrival of Post Financial Crisis Era and the rise of emerging economic entities, the status of large emerging countries rises significantly in global governance system. The status of G8 as global governance monopolist gradually declines, and G20 shifts to the center of the stage from the edge of global governance stage. Besides, the composition of G20 indicates international political and economic problems need the participation of large emerging countries, and need to reflect interests and appeals of emerging economic entities. Without these importance emerging forces, any contemporary global significant problems cannot be well solved and cannot find effective solutions. Even so, developed countries and developing countries still have a huge wealth and knowledge gap. Emerging market countries still fail to reach the force structure which can surpass or replace western powers. Hence, except continuously pursuing sustainable development of economic society large in global governance, emerging countries should enhance cooperation with developed countries in global governance. Win-win can be achieved only through cooperation. Emerging countries can better voice to the world on the international stage only through cooperation. In a long run, 
large emerging countries will gain greater the right of speech, influence and creativity in global governance system, which is an inexorable trend.

\section{Global governance mode led by developed countries}

G7/G8 which consists of developed countries in the world plays an important role in global governance course and drives continuous change of global governance mode. After the end of Cold War, numerous severe global problems are facilitated. G7/G8 has no longer put the center of governance on maintaining and controlling hegemony contending by two poles, but turns to establishing new international political and economic order and maintaining the role of global governance center. At present, G8 has become the core of leading global governance and plays a key role in coordinating, governing and solving global problems. Global governance mode with G8 being the core makes developed countries and developing countries own unequal rights of speech and interests. Meanwhile, G8 manipulates international organizations in the name of global governance. "Strong north and weak south" pattern of international society is still not changed fundamentally.

\subsection{Global governance course led by developed countries}

1) Origin of G7/G8. In 1970s, overall economic situation in the world was not optimistic. Dollar crisis, gulf oil crisis, the collapse of "Bretton Woods" system, serious economic crisis in 1973-1975 broke out successively. Main capitalist countries were caught in economic vortex and economy deteriorated and declined. In order to coordinate macroeconomic policy of western countries, enhance economic cooperation of capitalist countries, solve economic and monetary crisis to revitalize western economy, the summit which America, Britain French, West Germany, Italy and Japan participated in was convened in July 1975 under the proposal of French. Meanwhile, they made a unanimous decision that the conference would be held once per year, and Canada was invited to participate in the conference in 1976. Thus, G7 formed. The 8th member state Russia attended some conferences of G7 summit in 1991. In 1997, G7 was accepted as a member stage. G8 was officially established.

2) Transformation of G7/G8. Since G7 marked by "rich state club" was established in 1975, G7 has adhered to jointly leading global economic order, improving macroeconomic management level, dominating international trade, enhancing dialogues with developing countries and coordinating the relationship with developing countries through cooperation. In the later period of Cold War, G7 regarded coordinating economy and containing the Soviet Union as the goal. The end of Cold War, the disintegration of the Soviet Union and the establishment of G8 made G8 start to transform and reposition its development objective. In 1997, Russia joined in G7. Then, G8 frequently invited leaders of developing countries to attend G8 summit so as to enhance dialogues among leaders. As global problems become increasing and complex, global governance difficulty increases continuously. Developed countries realize they must enhance dialogues with developing countries and listen attentively to interest appeal of developing countries in order to well solve global problems and maintain sustainable development of world economy. Since 2000, representative Asian countries and African countries have been invited to summit conference of G8 annually. This fully reflects role change of G6 in global governance and the functions of developing countries increasingly increase. Some scholars boil G7/ G8 transformation process down to economic era, political era and topic diversity era of world affairs management. To be more specific, the main topic in economic era is to enhance macro-policy coordination, promote sufficient employment, maintain stable exchange rate, facilitate trade liberalization and reform national financial order etc. In political era, the main topic pays more attention to development of world politics except economy, such as enhancing intervention of the countries beyond the group, repelling the countries of interest differentiation and striking international crime and terrorist organizations etc. As global problems increase continuously, the topics of submit also become richer and more diversified, such as reducing and exempting debts of developing countries, information technology development, international organization building, resource and environment problems.

3) Global governance of G8. G8 is an exclusive club which consists of the most powerful developed and democratic countries in the world. Highly developed economy and consistence of economic structure guarantee convergence of interest orientation of the group. They benefit from open international order and are almost in monopoly position in international trade and foreign investment. G8 is unwilling to change stable governance system and especially existing international political and epcn0mic order which contributes to benefit maximization. Thus, G8 is devoted to maintaining its role of "global governance center". Extensive attention of various countries in the world to all previous G8 submits undoubtedly intensifies the approval of G8 global governance leader to some extent. In political, economic and military fields, the basic pattern that large countries dominate international order is not changed fundamentally. Politically, among 5 permanent member states of UN Security Council, 4 states belong to G9. Economically, GDP of G8 member states accounts for about $70 \%$ of global GDP. Militarily, G8 includes 4 core large countries, and military expenditure accounts for more than a half of global total military expenditure. Through the development for over 30 years, G8 states have gradually formed a set of complete organizational structure with summit conference being the core. 
A series of policy coordination and practical mechanisms have been established for numerous concrete issues. As global topics rise and the range of topics expands, functional scope of G8 also greatly expands. Internally, domestic policies of member states are increasingly enslaved to collective discussion and decision making of G8. Externally, more and more international rules are formulated by G8, or formulated under the influence and manipulation of G8. Undeniably, G8 plays an important role in coordinating numerous international affairs such as politics, economy, safety and society, helping member states control domestic politics and promoting global governance of member states.

4) Global governance of G8-led international organizations. In numerous fields of global governance, international organizations play a decisive role. International organizations form international rules based on common interests of member states through coordinating, organizing and arranging member states for dialogue and negotiation. Current situation of international community is that, international organizations are still manipulated by big countries. Numerous international organizations including WTO, IMF and WB are still dominated or restricted by few developed countries. G8 controls formulation of global rules to a large extent through dominating the discourse tenor of international organizations. For example, IMF and WB have carried out the principle that voting is decided by capital share. Developed countries occupy over $60 \%$ voting power, while America owns $20 \%$ voting power for a quite long time. G8 controls the two international economic organizations, actually amounting to dominate international currency rules and international financial order. Seeing from WTO'S routine work and arrangement, only important market economy countries (especially G8) own the right of speech. Other big countries and small countries which own influence in other aspects cannot generate significant influence on WTO. For WTO's operation rules, G8 is the core which leads to formulate WTO trade rules. Thus, G8 member states enjoy sufficient decision-making power in WTO. It thus can be seen that G8 enjoys absolute right of speech in global governance through dominating international organizations and institutions, which fully reflects global governance mode led by big countries. In this process, interest appeal of developing countries is neglected, and unequal governance structure of international community forms.

\subsection{Defects of global governance led by developed countries}

Developed countries represented by G8 make important contributions to peace, stability, prosperity and sustainable development of international community during leading global governance. For example, in economic field, G8 plays an important role in coordinating international macroeconomic policy, creating free trade system, developing and reforming international monetary and financial system. However, due to its limitations, the defects in global governance are also obvious.

G8 system is faced with governance plight and crisis in global management due to its defects. Such cognition becomes increasingly explicit that, if G20 is not integrated in G8 system, it is no longer impossible to handle increasingly complex global problems only by G8. Andrew Kuper considers G8 is faced with "dual crisis": 1) the controversy of international community for G8 legality has existed for a long time; 2) this group ha been trapped in urgent validity problem. This makes G8-led global governance system has huge shortcomings. The leading status of G8 suffers doubts and challenges continuously in global governance. This makes G8 unable to offer timely and effective solution agenda and action plan in allusion to urgent and austere global problems. Currently, defects of global governance led by big countries mainly include limitation of G8 mechanism, low execution efficiency, the difficulty in fulfilling the promise and legality query of G8 system.

Firstly, seeing from G8 system arrangement, G8 is not a perfect international organization in the sense of International Law. Its system and regulations are loose, though some principles, norms and mechanisms formed by G8 work to some extent. This causes politics of G8 lacks sufficient and extensive constraining force. The deficiency in forcible measures is the weakness of G8. Global governance led by big countries loses effect to some extent. Secondly, seeing from execution efficiency, the direction and quantity of topics increase sharply, as global governance led by big countries increasingly expands, ranging from economic issue to politics, safety, society and environment. Thus, limitations of G8 become more and more obvious. Big countries thus continuously expand the topics and range of summits. Thus, contradictions emerge inevitably with the effect of problem solving. Hence, execution efficiency of G8 is questioned continuously. Thirdly, seeing from the perspective of fulfilling the promise, execution of G8's decisions mainly depends on conscious actions of member states and participants. Since solutions facilitated by the summit will generate interest differentiation and conflict, many decisions cannot be effectively executed and even become formalistic. High standard of G8 summit and low execution efficiency of member states form distinctive contrast. This also reflects the limitation of G8's ability to lead global governance and the necessity of reforming global governance mode. Finally, from the perspective of legality, although the range of G8 topics is expanding continuously, this decision-making mechanism of "rich people" cannot reflect interest appeal of vast developing countries. Thus, G8 continuously suffers queries from emerging economic entities and developing countries about the status of global governance center, including the legality, representativeness and transparency. This also indicates under new historical background where global political and economic force domain is allocated again, it is unrealistic to manipulate international affairs and dominate global 
governance only by several developed countries, which will certainly suffer criticism and distrust of international community. This also becomes the root of G8 losing legality of global governance.

\section{Role change and interest appeal of emerging economic entities in global governance}

Emerging economic entities refer to the countries with high-speed economic development and huge market potential beyond developed countries which own important influence in global and local political and economic affairs. Emerging economic entities cover extensive Asia, Africa and Latin America and mainly include China, Russia, India, Vietnam, Brazil, Mexico and South Africa etc. These large emerging market countries gradually move to the center of the stage from the edge of global governance stage and play an increasingly important role in current international political and economic domain. Meanwhile, they play a core role in representing regional interests, promoting local economic prosperity and maintaining regional peace and stability. In recent years, emerging market countries represented by BRICs and G20 has risen as a whole. Emerging economies such as China, Russia, India and Brazil have vast territory, abundant resources, large population, expansive domestic market and huge consumption potential. Meanwhile, they own strong capital adjusting ability and crisis solving ability. Global economic crisis makes economy of developed countries sluggish. Rapid and stable development of emerging entities plays a key role in solving economic crisis and restoring market confidence. Undeniably, emerging entities will become a new growth point of world economy. Of course, emerging entities also own their own interests and appeals in each field of global governance. These appeals intensively reflect the wish of developing countries. Only when emerging countries jointly "voice" in global governance can they strive for the maximum right of speech, maintain common interests and change the governance pattern of dominance by developed countries.

\subsection{Role change of emerging economic entities in global governance}

Emergence of G7/G8 and G20 is inseparable from changes in global political and economic form. A series of economic crises in 1970s facilitated the emergence of G7. Financial crisis in Asia in 1997 also made G20 represented by emerging economic entities walk on the global stage. In 2008, global financial crisis broke out. G8 realized cooperation with developing countries in global governance must be enhanced in order to effectively solve crisis. After that, the conference of finance ministers of G20 and president of Central Bank created in 1999 officially upgraded to G20 leadership summit. G20 walking on the stage of history means brand-new historical status of emerging economies and new political and economic pattern emerge. The limitation of G8 in global governance and historical trend that emerging economic entities increasingly become new engine of global economy make the tide of world multipolarization advance irresistibly. Since global financial crisis, G20 has become a main international governance platform. The emergence of G20 mechanism generates profound influence on global governance structure. Emerging economic entities also achieve role change in this process.

Firstly, emerging economic entities change the function of G8 in global governance. Just as the report issued by US Department of Commerce said, emerging markets were rising and in the future America would contend with these emerging economic entities; emerging economic entities will alter the pattern of world economy and rewrite political rules to a larger extent. The fact proves that G8 governance mode and its influence started to decline in late 1990s. After financial crisis in 2008, global economic governance capacity of G8 declined again, and this further accelerated the change of global governance mechanism. Emerging economic entities marked by G20 advocate various countries undertake joint responsibility in global problems and especially stress developed countries and developing countries jointly perform historical mission of sustainable global economic development through dialogue and cooperation. Global governance mechanism changes to joint dominance by developed countries and developing countries from developed countries.

Secondly, emerging economic entities reform and reconstruct new international economic and financial order. Since 1970s, G8 has served as the leader to solve global economic issue. The resolutions and schemes discussed in the group reflect the interests of developed countries, and fail to reflect the appeals of developing countries. Through the development for several decades, emerging economic entities change its edge status in world economic pattern to a large extent in the 21st century. In Pittsburgh Summit held in September 2009, the share and voting power of developing countries represented by emerging economic entities in IMF and WB increased by 5\% and 3\%, respectively. Thus, global economic governance pattern controlled by G8 was broken. Relevant predications indicate that in future 30 years, total GDP of emerging market countries will surpass mature economic entities. The rise of emerging market countries makes G20 become the major platform of international economic cooperation, boost the right of speech of developing countries in international economic and financial field, break international economic order led by developed countries and drive formation of new international economic order. In the era of G8's global governance, emerging market countries attend the conference only in the capacity of observer. In the framework of G20, emerging market countries represented by BRICs start to jointly discuss global economic problems with G8 member states and seek 
countermeasures and solutions. This breaks "center-periphery theory" of western economics and makes world economic decision-making develop to balanced direction.

Thirdly, in the framework of G20, BRICs gradually become the spokesperson of developing countries with emerging market countries being the core. G8 only includes few developed countries, while G20 integrates dual forces of developed countries and developing countries. In the face of crisis, G20 has better flexibility and buffer space, drives cooperation of man economic entities in the world and achieves comprehensive recovery of world economy. BRICs are the most vigorous representative group in G20. Its economic scale, total quantity of market and economic growth rate become the new highlights of current international economic field. BRICs act as the role of spokesman of G20 and play an important leading role in guiding emerging economic entities to participate in global governance, exploring solutions of financial crisis, opposing trade protection, stimulating economy, jointly coping with climatic change and achieving equal status of developing countries and developed countries.

\subsection{Interests and appeals of emerging economic countries}

The emergence of G20 indicates the influence of emerging market countries further expands. Represented by BRICs, emerging economic countries reach a profound consensus in the aspects of reforming international monetary and financial system, opposing trade protectionism, and jointly coping with financial crisis. In fact, interests and appeals of emerging economic entities are more than these. Fundamentally, global governance needs to develop towards equilibrium, mutual benefit and win-win. Interests and appeals of emerging economic entities cover multiple fields including economy, environment, energy and development. All these prominently reflect the aspirations of most developing countries in the world.

1) Economy and trade field. In June 2009, the conference of finance ministers of G8 was convened. Each participant once promised to keep trying to strive for accomplishing Doha Round negotiations, while developed countries had realized Doha round negotiations could not be completed only by G8. Only with the consent of emerging economic entities, negotiations can evolve substantially. Doha Round strove to promote global economic development and especially economic development of poor countries through fairer trade environment and aimed to achieve reduction of trade barriers of WTO members. In this process, interest appeal of emerging economic entities is to cut down and cancel tariff peak, promote market access of developing countries and cooperate to develop markets of underdeveloped countries, contain trade protectionism, reduce anti-dumping and anti-subsidy and seek more equal trade status. Interest inconsistency between developed countries and developing countries in result in stranded negotiations. In the past, global economic governance was basically dominated by developed countries, while representativeness, right of speech and decision-making power of emerging countries in international economic institutions are insufficient obviously. Hence, driving global governance to develop towards equality and reciprocity is the interest appeal of developing countries. Emerging economic entities should improve benefit right, right of speech and decision-making power in important international economic organizations such as WTO, IMF and WB. International economic governance structure should properly incline to developing countries represented by emerging economic entities.

2) Financial field. Interest and appeal of emerging economic entities in financial field is mainly reflected in improvement of representative right in international financial institutions. In G20 London summit, emerging economic entities represented by BRICs countries express their interest appeal. China considers after international financial crisis, the defects of existing international financial system have become very obvious. Thus, it is very important to deepen reform of current international financial system. In this process, China should give play to more active functions and deeply participate in reform practice. Russia highly approves China's proposal of establishing "super-sovereign reserve currency" and advocates to reform international monetary system. Brazil emphasizes to change global loan mechanism led by IMF and to explore establishment of a new international capital flow adjustment mechanism so as to reduce the loss risk of emerging economic entities suffering financial crisis. On the conference of finance ministers of "BRICs" and the president of Central Bank, the common voice of China, Russia, Brazil and India is to substantially transfer the shares of IMF and WB to developing countries represented by emerging economic entities. Only when emerging economic entities continuously enhance internal cohesive force and seek cooperation and game with developed countries can a fair and rational international economic and financial order be established.

3) Climatic issue. Emerging economic entities have submitted the draft to Copenhagen Climate Conference, oppose emission reduction goal proposed by developed countries and appeal to developing countries to fulfill corresponding emission reduction actions, while developed countries need to undertake emission reduction obligation with legal force. Developed countries are vague in terms of offering technical and capital support for coping with global warming to developing countries, or developed countries additionally increase numerous constraint conditions, which makes emission reduction of developing countries become more difficult. Developed countries not just try every means to escape quantitative emission reduction task as of middle 2020, but also turn major spearhead to few developing 
countries to transfer emission reduction task and negotiation focus. Compared with irresponsible developed countries, emerging economic entities such as China, India and Brazil take the lead to set an example to perform emission reduction obligation and gain extensive approval of international community. United Nations Framework Convention on Climate Change and Copenhagen Agreement specify the principle of "common but different responsibility" of developed countries and developing countries. Thought the establishment of double-track negotiation architecture, mandatory emission reduction norms are adopted for developed countries, while autonomous slow-down scheme according to development stage and practical development condition is adopted for developing countries. It thus can be seen that interest appeal of emerging economic entities is that developed countries can specify development history and emission reduction pressure of developing countries, jointly undertake the reasonability and obligation of emission reduction and give developing countries powerful technical and financial support so as to cope with global climate change.

4) Energy issue. In recent 30 years, world energy consumption grows substantially. Since emerging market countries are in the rapid development stage, the demand for energy is growing increasingly. Rapid growth of energy demand of emerging economic entities gives rise to huge pressure to international energy system. Existing energy system needs urgent reform. For example, IEA fails to bring large emerging energy consumption countries in the decision-making level. Due to the lack of extensive and deep participation mechanism for large emerging energy consumption countries, the balance of current international energy governance pattern has been broken. On IEA conference held in 2009, non-OECD member states - China, Russia and India attended the conference the first time in the capacity of partners. The conference result was that the cooperation in energy safety, energy conservation, emission reduction, technology research and development would be conducted in the future, and long-term friendly cooperation with the above three OECD member states would be kept. Interest appeal of emerging economic entities is that the framework of international energy governance should be brought in large emerging energy consumption country; developed countries should share energy technical innovation with emerging economic entities and boost energy use efficiency; main energy institutions should ensure stable energy supply and maintain stable energy price; main economic entities should join hands to strike energy speculation; energy utilization transformation should be jointly achieved worldwide.

5) Development issue. With rapid development of globalization, developed countries must coordinate with rising emerging economic entities in developing countries, enhance cooperation, adopt strong points and avoid weak points and jointly explore a new mode to govern global development issue. Developed countries should attach importance to interest and appeal of developing countries, show political sincerity and actual actions, enhance financial and technical support of developing countries, practically fulfill assistance promise for developing countries, strive to narrow the development gap between the south an the north and achieve common development. International organization should first help developing countries represented by emerging economic entities in terms of newly increasing energy and offer loan support to emerging economic entities in a more flexible, diversified and convenient way. Emerging economic entities are the backbone of developing countries. Their interest appeal is reflected in that developed countries and international organizations are expected to give sufficient support in loan, resource, knowledge and technology, and to help more behindhand developing countries get rid of poverty, revitalize the economy and achieve mutual assistance. The growth of developing countries also contributes to enhancing cooperation and dialogue between the south and the north.

\section{Change impetus and development tendency of global governance mode}

Change impetus of global governance mode mainly includes objective and subjective aspects. From the objective level, further deepening of globalization makes market economy continuously extend. Integration of world economy forms gradually. Interdependency of various countries in the world becomes closer and closer. The formation of interdependent international economic system not just makes each country own unprecedented development opportunity, but also makes challenges and crisis faced by each country further intensify. Hence, traditional global governance mode led by large countries cannot effectively offer effective governance of worldwide management organizations and cooperation arrangement. Meanwhile, globalization causes a series of new global problems emerge in endlessly. Global governance no longer just stays at economic level. Safety problem, ecological problem, development issue and other new topics are in front of various countries in the world. Their scale, range and influence are global. International community needs mutual cooperation to effectively cope with these problems. Objective complexity of global problems decides unilateral or several lateral actions must be replaced by multilateral joint actions. The change in traditional global governance mode is extremely urgent. From the subjective level, efficiency, fairness and authority of developed countries such as G8 continuously suffer challenges. They are barely satisfactory in handling international affairs and especially coping with global economic crisis in 2008. With the rise of emerging economic entities, they are the backbone in global economic recovery. They not merely own huge development potential, but also can effectively cope with crisis and own numerous interests and appeals. Thus, global governance mode purely led by developed countries 
cannot well solve world difficulties faced, let alone reflect the wish of vast developing countries represented by emerging economic entities. Such global governance will certainly lose practical significance and intrinsic value. Thus, global governance mode jointly led by developed countries and developing countries will be an irresistible trend. Seeing from development trend of global governance, firstly, the rise of emerging countries will play a more important role in global governance. New global governance mechanism marked by G20 will generate great influence on future global governance trend. Secondly, "mosaic" trend of global governance mode becomes increasingly obvious. The participation of transnational non-governmental organizations and civil social group will form global governance mode with rich and diversified participation layer and participation mechanism together with traditional national states and international organizations. Thirdly, decision-making environment and practical link of global governance will be more influenced by global digital evolution. The scope of global governance will become wider and wider. Developed countries and developing countries will finally form cooperation and win-win new pattern under new global governance mode.

\section{References}

Cao, L. J. (2005). G8 and Contemporary World Pattern, Beijing: People's Publishing House.

Hu, A. G. (2007). Participation in Global Governance: Inevitable Choice of China Energy Strategy, Beijing: Economic Information Daily.

Huang, R. W. (2009). Advantages and Disadvantages of Participation in Global Governance by Large Emerging Countries, Modern International Relations, 11, 21-22.

Lu, X. J. (2006). China and G8, Beijing: Current Affair Press.

Lv, Y. C., Li, X. F., \& Zha, J. H. (2006). G8 and China, Zhejiang: Zhejiang University Press.

Michael, B., \& Raymond, D. (2005).Power in global governance, New York: Cambridge University Press.

Xu, H. C. (2010). Giving play to Functions of G8, G20 and BRICs in Global Governance, Beijing: Social Sciences Academic Press.

Yu, K. P. (2002).Introduction to Global Governance, Marxism and Reality, 1, 20-32.

Zhou ,Y. (2009). On Reform of International Financial System, Study on World Economy, 5, 23-28.

\section{$(\mathrm{cc}) \mathrm{BY}$}

This work is licensed under a Creative Commons Attribution 3.0 License. 